"Transformation and development towards a fully inclusive society and economy in the City of Johannesburg, South Africa"

\begin{tabular}{|c|c|c|}
\hline AUTHORS & \multicolumn{2}{|l|}{ Paul Kibuuka } \\
\hline ARTICLE INFO & \multicolumn{2}{|c|}{$\begin{array}{l}\text { Paul Kibuuka (2017). Transformation and development towards a fully inclusive } \\
\text { society and economy in the City of Johannesburg, South Africa. Public and } \\
\text { Municipal Finance, 6(1),63-74. doi:10.21511/pmf.06(1).2017.07 }\end{array}$} \\
\hline DOI & \multicolumn{2}{|c|}{ http://dx.doi.org/10.21511/pmf.06(1).2017.07 } \\
\hline RELEASED ON & \multicolumn{2}{|l|}{ Wednesday, 05 April 2017} \\
\hline & \multicolumn{2}{|c|}{$\left(\right.$ (c) EY-NC $_{1}$} \\
\hline LICENSE & \multicolumn{2}{|c|}{$\begin{array}{l}\text { This work is licensed under a Creative Commons Attribution-NonCommercial } 4.0 \\
\text { International License }\end{array}$} \\
\hline JOURNAL & \multicolumn{2}{|l|}{ "Public and Municipal Finance" } \\
\hline ISSN PRINT & \multicolumn{2}{|l|}{$2222-1867$} \\
\hline ISSN ONLINE & \multicolumn{2}{|l|}{$2222-1875$} \\
\hline PUBLISHER & \multicolumn{2}{|c|}{ LLC "Consulting Publishing Company "Business Perspectives" } \\
\hline FOUNDER & \multicolumn{2}{|c|}{ LLC "Consulting Publishing Company "Business Perspectives" } \\
\hline \multirow{2}{*}{ NUMBER OF REFERENCES } & & 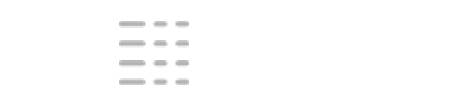 \\
\hline & NUMBER OF FIGURES & NUMBER OF TABLES \\
\hline 20 & 12 & 1 \\
\hline
\end{tabular}

(C) The author(s) 2022. This publication is an open access article. 


\title{
Transformation and development towards a fully inclusive society and economy in the City of Johannesburg, South Africa
}

\begin{abstract}
This paper analyzes the state of economic growth and development in the City of Johannesburg (COJ) South Africa as by the year 2016 and presents a case for transformation and development of the City towards a fully inclusive economy and society. The research reveals that faster and sustainable economic growth in addition to proactive pro-equity policies are a sine qua non for inclusive growth and participation in the City, where the triple challenges of poverty, inequality and unemployment persist more than 20 years into the democratic dispensation. During the last 17 years the City economy has grown at almost the same pace as the national South African economy with a trend reflective of major world economic events. Going forward, the South African economy is projected to grow at less $2 \%$ annually in the next 3 years. In terms of the City, the prognosis is that the City will either continue to trace the national economic growth rate or decline from $2 \%$ in 2016 to $1 \%$ in 2018. In order to achieve the objectives and goals of the Johannesburg 2040 Growth and Development Strategy in the long term and the City Integrated Development Plan in the medium term, the City leadership and administration will need to begin by not only addressing factors that inhibit economic efficiency including crime and corruption, but also the provision of a critical pipeline of skills required by industry in order to attract local and international investment. The increase in investment is expected to broaden the revenue base and to strengthen the financial capacity of the City to roll out services to the previously disadvantaged communities so as to bring them into the mainstream of economic empowerment and social transformation.
\end{abstract}

Keywords: economic growth, inclusive growth and participation, social transformation, medium-term budget, operating surplus, Johannesburg 2040 Growth and Development Strategy and South Africa.

JEL Classification: $\mathrm{O} 43$.

\section{Introduction}

Cities are engines of national and global growth. Urban areas account for half the world's population, but generate around $80 \%$ of global Gross Domestic Product (GDP) (Floater, 2014). According to the McKinsey's cities report (2012), cities have been the world's economic engines for centuries, attracting skilled workers and productive businesses and benefitting from economies of scale. Urbanization and per capita GDP tend to move in close synch, as countries develop, but what is different about today's wave of mass urbanization is its unprecedented speed and scale. The increasing size and power of cities in emerging markets have tangible and dramatic economic benefits that translate into rising incomes.

It is estimated that 80 percent of South Africa's population will be living in cities by 2050 . The challenge for the metropolitan councils like the City of Johannesburg during this period of time is going to be sustainable transformation to bring about inclusive economic participation for all citizens through skills development, increased productivity and strong employment equity programmes in order to ensure broad based financial freedom.

(C) Paul Kibuuka, 2017

Paul Kibuuka, Associate Professor at University of South Africa (UNISA), South Africa.

This is an Open Access article, distributed under the terms of the Creative Commons Attribution-NonCommercial 4.0 International license, which permits re-use, distribution, and reproduction, provided the materials aren't used for commercial purposes and the original work is properly cited.
Therefore, national, provincial and local governments, as well as businesses need to manage the consumption and investment boom effectively, because the urban planning and infrastructure investment choices made today will determine how well cities are prepared for sustained growth and equitable distribution of resources when the expansive urbanization wave passes.

\section{Theoretical model for inclusive economic growth}

Development economics is witnessing a paradigm shift from Pro Poor Growth to inclusive growth. A typical theoretical model of inclusive growth in a given region, as reflected in Figure 1, exhibits 8 key drivers. First and foremost, faster and sustainable economic growth is a pre requisite for inclusive growth and participation. Perhaps this best explains why the emerging economies like Brazil, China and India focused more on accelerated economic growth in the last couple of decades. Economic growth results in increased revenues for government in order to provide basic socioeconomic amenities in the form of food for all, health for all, education for all, electricity for all, access to all weather-good roads and safe drinking water. Government at all spheres should achieve administrative efficiency and should guarantee gender and employment equity so that the trickle-down effect of the growth will actually materialize. Good governance, gender and employment equity will enhance the human capabilities. Followed by economic growth, productive employment is the key driver of inclusive economic growth, since jobless growth is as dangerous as stagnation. Productive 
employment can increase the labor productivity and is an important outcome of inclusiveness. Naturally employment should be capable of poverty reduction. Inclusive growth assumes significance, since it alone can uproot the absolute poverty. Inclusive growth can substantially reduce income inequality, both vertical and horizontal, resulting in enhanced quality of human capabilities (Vellala et al., 2014).

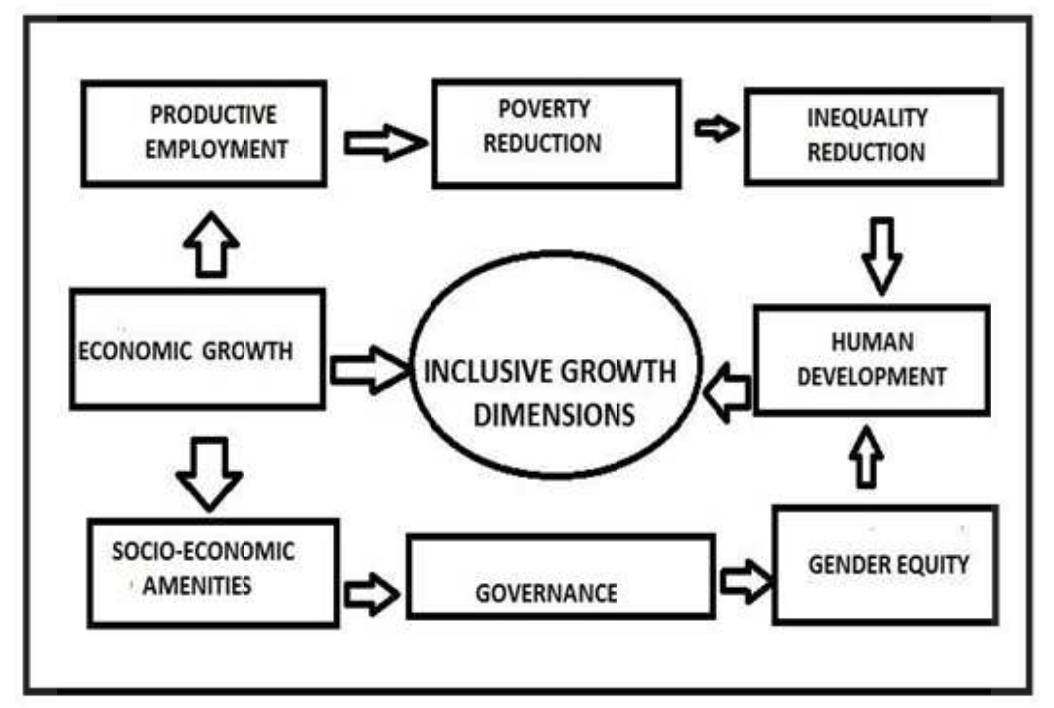

Fig. 1. Theoretical model for inclusive economic growth

Source: Vellala et al. (2014).

\section{State of the economy of the City of Johannesburg (COJ)}

2.1. Overview of production and economic growth. 2.1.1. COJ fifteen point economic development plan. The City of Johannesburg's benchmark economic development blue print is the fifteen point economic development plan of 2014 (COJ, 2014). The Plan has the 2011, Johannesburg 2040 City Vision as its foundation and is informed by the City Economic Development Strategy 2008/09 and the City Economic Transformation Policy Framework of 2011. The Plan is also informed by international, national and provincial imperatives, policies and plans including the National Development Plan and the New Growth Plan.

The 2014 fifteen point economic development plan has three agendas into which fifteen Plan elements are organized: improving overall competitiveness of the city; undertaking an industrial-spatial economy program: improving role-player accountability and implementation.

2.1.2. COJ breakthrough interventions for Johannesburg Economic Development Strategy 2015. According to the Economic Development Strategy (2015), Johannesburg's economy is now diversified and largely services based with around three quarters of the GDP originating from the tertiary sector. Although the employment rate is better than other South African cities, unemployment remains the major structural economic challenge. As a result, the apartheid era legacies of inequality and poverty persist well into the democratic era. The employment challenge is steepened by the influx of job seekers from elsewhere in South Africa and abroad contributing to average rate of population growth over the past ten years more than double that of the country at $3.1 \%$ per annum compared with $1.3 \%$ per annum, respectively. Two fundamental but practical outcomes are proposed for the City's economic development strategy: faster growth of the city economy, leading to higher employment, output and incomes, higher city revenues in order to fund ongoing city service delivery and social and economic transformation and development initiatives, economic empowerment of the poor and disadvantaged, which supports further transformation towards a fully inclusive society and economy.

\subsubsection{Gross value added and economic} composition. The City of Johannesburg contributed $14.7 \%$ of the total Gross Domestic Product of South Africa in 2010 constant prices for the year 2014. Figure 2 demonstrates that the growth trend of the gross value added for the City of Johannesburg has over the last eight years traced that of South Africa at the national level with a trajectory characteristic of major world economic events. According to the South African Reserve Bank (2007), on the global and national level from 1997 and most of 1999 was the downward phase of the South Africa economic business cycle, which was exacerbated by the Asian financial crisis, but the downward cycle, then, started to give way to a recovery in general economic activity, with the South African economy entering an upward phase of the business cycle in September 1999. 


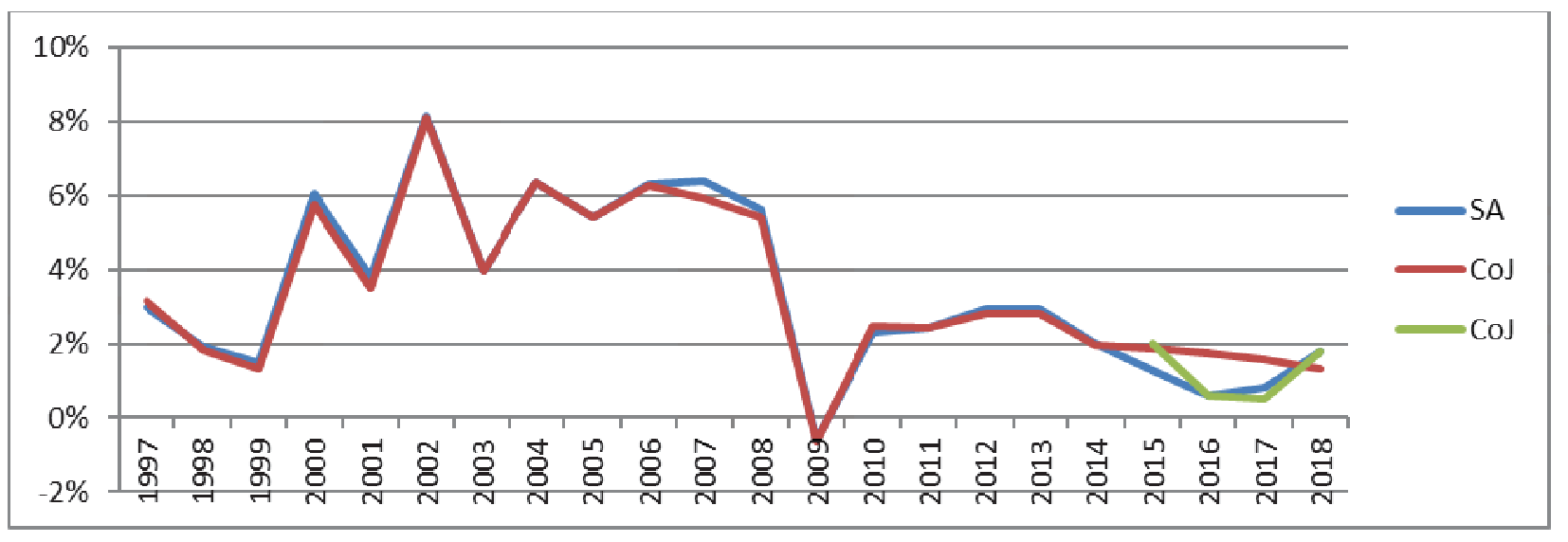

Fig. 2. Year on year GDP growth rate, 2010 constant prices SA and COJ

Source: data adapted from Global Insight IHS (2015) \& SARB (2016).

From about the second half of 2003, the global economy gathered momentum and continued to grow briskly until 2007. This period was characterized by a number of factors, which included the continued and rapid rise in international commodity prices, notably crude oil prices; and rapid economic growth in most emerging-market economies, particularly in China, India and other Asian countries. This was accompanied by widening current-account imbalances in a number of countries. Furthermore, consumer price inflation moderated worldwide, resulting in a fairly accommodative monetary policy stance globally. In addition, marked increases were recorded in the international prices of most assets, especially those of shares, bonds and residential property.

As indicated in Figure 2, the South African economic growth rate during this period of time ranged from $3 \%$ in 2010 to $1.3 \%$ in 2015 . Based on an internal macroeconomic probabilistic model, the Unisa Bureau of Market Research (BMR) projects the South African economy to grow at $0.6 \%$ in 2016 and $0.8 \%$ in 2017 impacted by both domestic and global factors including low commodity prices, the economic slowdown in our trading partners including China and the Eurozone, global geopolitical risks, the persistent draught, higher electricity tariffs, stable but unpredictable power supply, low household consumption expenditure, domestic governance and political risk on the back of amongst others the South African August local government elections, volatile markets, high inflation and high interest rates. Thereafter, the economy is expected to start registering an upward growth trend in 2018 on the easing of the downside risks to growth. Another important global factor is the aftermath of the November 2016 US presidential elections where the President elect expansive domestic policy points to higher infrastructure spending, the possibility of higher inflation and interest rates.
In this regard, economic growth in the City of Johannesburg from 2015 to 2018 is predicted to take two paths: firstly utilizing the autoregressive moving averages the economy is expected to grow higher than the South African economy, but continue a down ward trend for the next two years recording a growth rate of $2 \%$ in 2016 and 2017 and declining to $1 \%$ in 2018 , respectively. On other hand, based on past experience the performance of the COJ economy may continue to align with the growth rate of the national South African economy to register close to $0.6 \%$ in 2016, $0.8 \%$ in 2017 (BMR) and $1.8 \%$ in 2018, respectively, as predicted by the Monetary Committee of the South African Reserve Bank earlier on in 2016. The implications for the slower economic growth for the City will be lower fiscal revenues raised locally from charges, rates and taxes, but also transfers from the national treasury resulting in the need to scale down on the delivery of social economic programmes.

2.1.4. COJ key economic sector overview. Analyzing the trends in the current primary, secondary and tertiary sector structural change in Figure 3, the reality is that the percentage of the tertiary sector contribution to the COJ Gross Domestic Product has increased by more than $10 \%$ in the last 18 years, while the contribution of the secondary sector has dropped by almost $10 \%$ over the last 18 years. The primary sector contribution though consistently very small has dropped by about $1 \%$ over the same period.

The Economic Development Strategy for the City of Johannesburg (2015) identified specific sectors to stimulate economic activity and progressively empower the poor to participate in the economy, namely: building on existing sector and niche economic strengths, for instance, in the financial and mining service sectors; encourage growth of manufacturing industries with significant potential for local development of forward and backward 
linkages and with potential for positioning in global value chains; encourage development in sectors which can employ significant numbers of lower-skill workers, but which can offer significant on-job training and skills transfer; facilitate development of sustainable micro and small business and encourage their growth into sustainable larger scale enterprise; improve access to job opportunities by locating job creating investments closer to where large concentrations of unemployed people live and improving mobility of workers within the city.

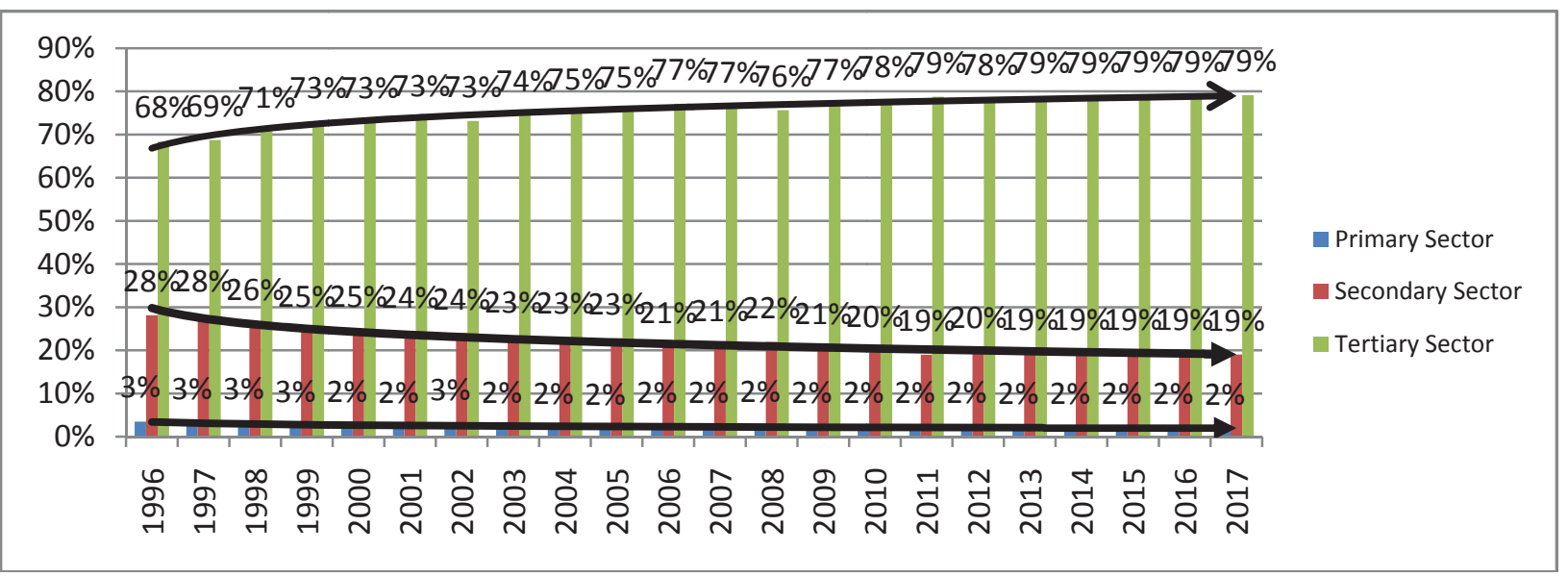

Fig. 3. COJ primary, secondary and tertiary sector structural change 1996-2017

Source: data adapted from Global Insight IHS (2015).

2.2. Key sector growth trend analysis. The Johannesburg 2030 Strategy highlights that there are problems in the City with business transport, with telecommunications infrastructure, with market access and penetration and with the mix of economic activity. The two biggest problems related to the economic efficiency of the City, however, are none of the above, but are rather: crime and a mismatch of skills between industry demand and labor market supply. The report emphasizes that in the absence of addressing these shortcomings, the City will be unable to entice local or international investment. In the absence of such investment, there will be no new jobs and, hence, increased poverty and unemployment.

With respect to economies of localization, the report shows that Johannesburg has traditionally been very effective in this area, but that the industries which the city is set up to support are at present sunset industries (mining and heavy primary production). The economy has changed and growth in the City is now generated by the service sectors. The City infrastructure and efficiencies must now be geared towards this new trajectory, hence, a lot of work remains to be done in this area. Figure 4 presents the growth trends of all the 9 major sectors in the City for the last 21 years. The trends indicate that the tertiary sector is dominating the economy with a preponderance of finance, community services and trade. Clearly based on Figure 4, the disparities between tertiary and primary industry are increasing.

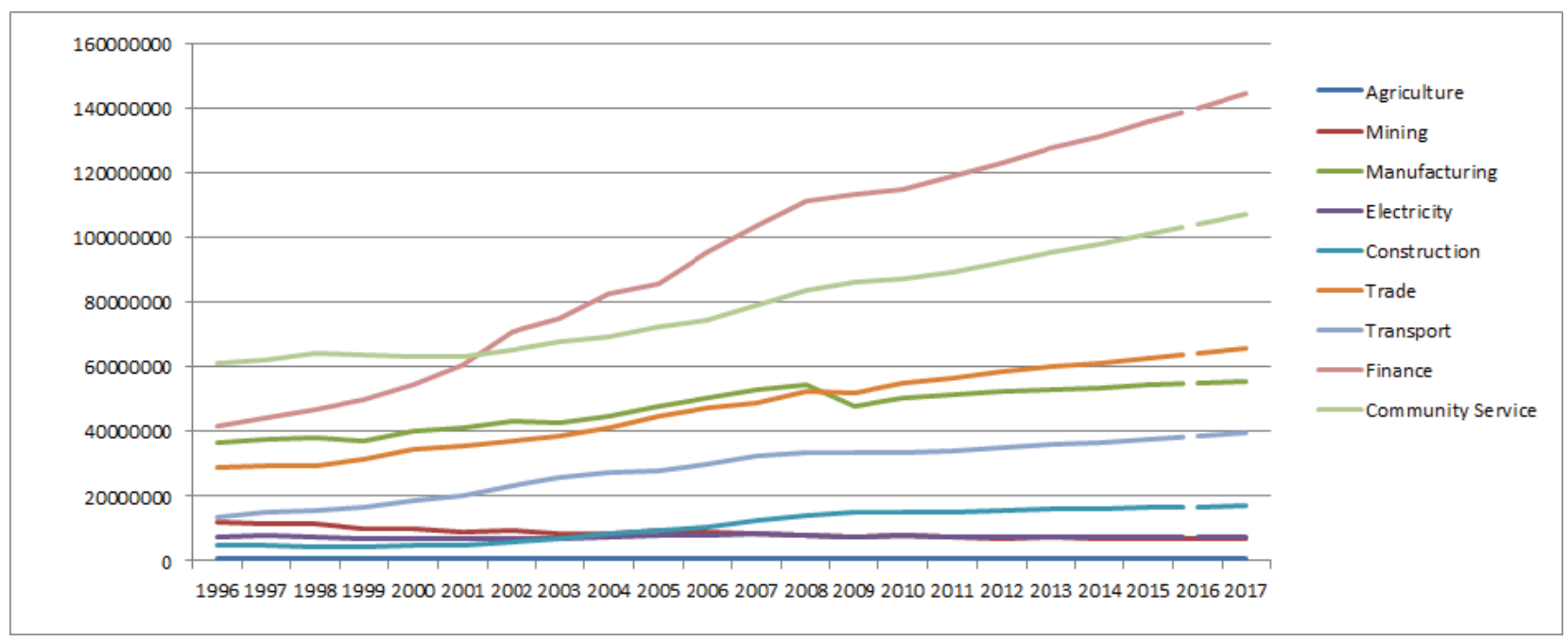

Fig. 4. Overview of growth of all economic sectors in COJ: 2010 - R'000 constant prices Source: data adapted from Global Insight IHS (2015). 
2.2.1. COJ economic output composition. The total Gross Domestic Product of the City in 2014 amounted to R412, 1 billion in 2010 constant prices. The services sector now accounts for $78 \%$ of the City's economy. As indicated in the previous section, the main sectors of the City's economy are finance, community services, trade and transport. The City of Johannesburg is a two speed economy dominated by the tertiary sector. The second outcome of the Johannesburg 2040 Growth and Development Strategy commits the City to provide a resilient, liveable, sustainable urban environment underpinned by infrastructure supportive of a lowcarbon economy through leading in the establishment of sustainable and eco-efficient infrastructure solutions such as housing, ecomobility, energy, water, waste, sanitation and information and communications technology. The results in Figure 5 provide an indication of the performance against the City's commitment and journey towards implementing this goal. This structure replicates the South African national economic structure.

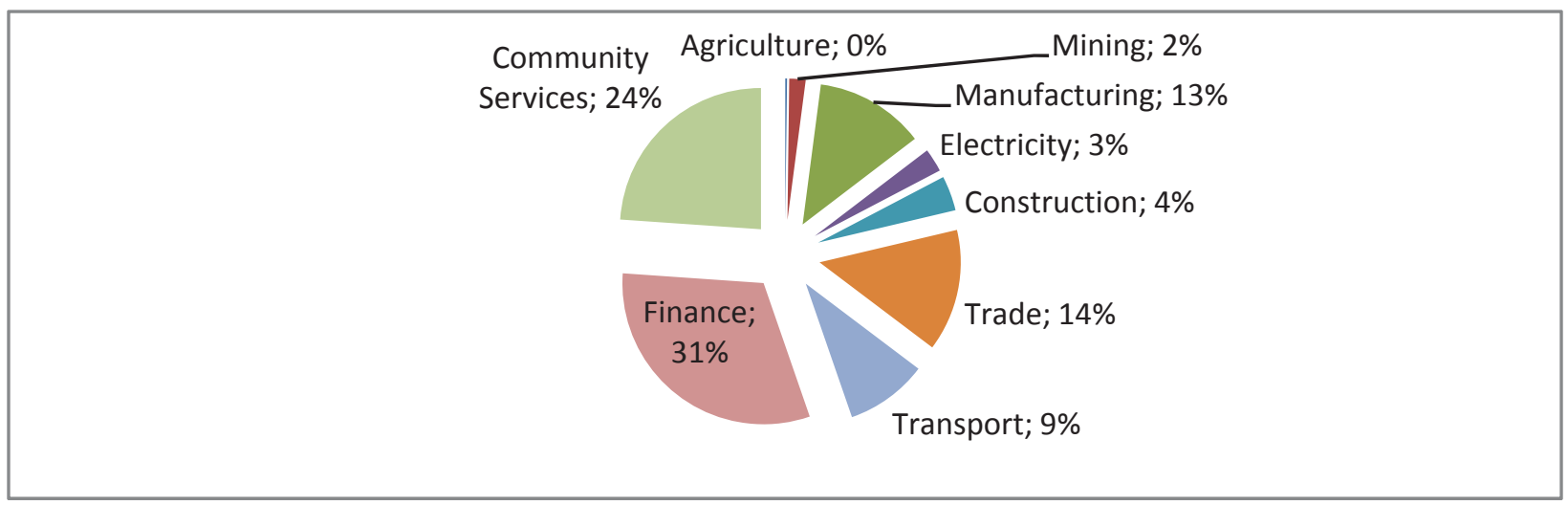

Fig. 5. Gross value added composition of the COJ 2014

Source: data adapted from Global Insight IHS (2015).

2.3. COJ labor market. 2.3.1. Employment trends in COJ. Data for the year 2014 indicate that the biggest formal employment sectors in the economy of the City of Johannesburg are finance, followed by trade, community services, manufacturing and households amongst others. Total formal employment in the 9 broad economic sectors stood at 1734358 in 2014. The growth in employment $(2.8 \%)$ is not adequate to meet the NDP target of $5.4 \%$ per annum. According to the World Economic Forum Global Competitiveness Report (2016) rankings, for South Africa, worrisome are health (128th) and the quality of education (120th), where higher secondary enrollment rates are projected not be sufficient to create the skills needed for a competitive economy.

As reflected in Figure 6, manufacturing in the City of Johannesburg declined from the second largest employer in 1996 to the fourth in 2014. The sector levels of employment slowed down from 1996 year on year stabilizing in 2013 and 2014. Finance is the largest employer with over 500000 people in 2014. Trade is the second largest employer followed by community services. It is evident from the graph that community services have experienced steep growth since 1997 overtaking manufacturing in 2001, significantly narrowing the gap and threatening to overtake trade in 2014.

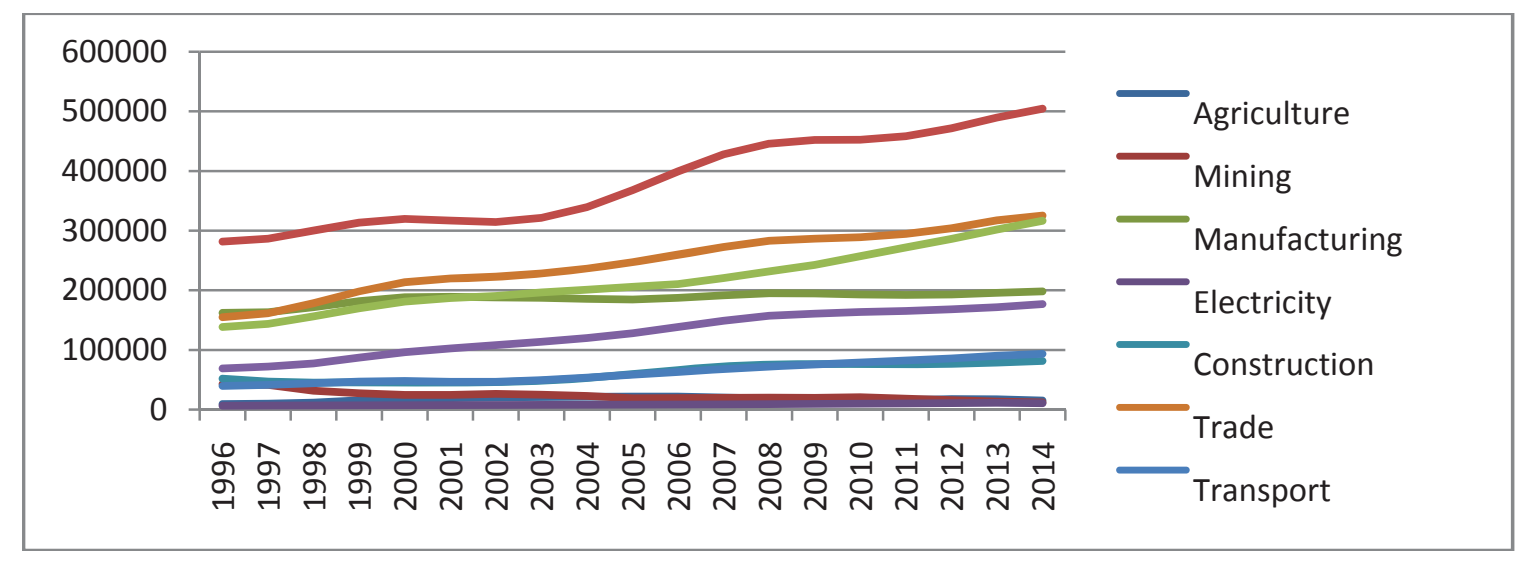

Fig. 6. COJ formal employment trends 10 sectors 1996-2014

Source: data adapted from Global Insight IHS (2015). 
Based on the analysis conducted during this study, it emerges that the total primary sector contribution to employment in the City of Johannesburg is small and shrinking in both actual and relative terms. The decline is equitable both in terms of mining and quarrying, as well as agriculture, forestry and fishing. Given the rate of population growth and high structural unemployment, faster economic growth alone will not be enough, the pattern of economic activity will have to support a higher aggregate rate of labor absorption than currently the case. This implies a multi-dimensional strategy, which targets the support, development and growth of the entire spectrum of business enterprise in the City ranging from the informal sector and micro enterprise to multi-national corporations. The aim should be to broaden economic participation and inclusivity in order to improve household incomes in the City with a view to increase consumption of both goods and services resulting in higher revenues and operating surplus for the metropolitan government to fund the delivery of social services.

Employment contribution by the secondary sector has increased in actual terms year on year, but exhibited a declining trend in relative terms. Construction has experienced a rise in job numbers mainly due to public sector driven infrastructure projects and labor intensive methods. In relative terms, manufacturing contribution to employment has declined due to higher input costs, constrained demand and increased global competition.

As a result, the City Economic Development Strategy (2015) expresses the need to stimulate economic activity and progressively empower the poor to participate in the economy. In this regard the economic strategy has targeted a number of practical objectives: positioning the City as a regional commercial hub for Southern Africa: attracting and retaining enterprise investment in the City as a necessary condition for economic development and growth: reclaiming and revitalising low or non-revenue generating parts of the city such as vacant land, underperforming industrial land and areas of the inner city subject to decay; pursuing a 'return on investment' approach to City capital investments, meaning greater alignment of City infrastructure development and capital expenditure programs with economic development thrusts; promoting development of sectors and City services that will lead to productivity improvements such as ICT and transport logistics networks, thus, making the City more attractive as a business location; developing small to medium sized enterprises; prioritizing provision of economically empowering infrastructure such as ICT hotspots to poor communities with latent economic potential; promoting incremental advancement along a viable economic development route to an inclusive economy.

In terms of the tertiary sector, all subsectors have experienced job growth with finance, trade and community services being the largest subsectors. Trade, in particular, comes number 3 in terms of contribution two GVA, but leaps to number 2 after finance in terms of providing the largest number of jobs.

\subsubsection{Unemployment in the City of Johannesburg.} The not economically active population of the City of Johannesburg is the main contributing factor to the drop in the percentage of those unemployed. Figure 7 presents the unemployment rates of the eight South African metros. Five of the eight metros manifested out right declining trends in unemployment rates during the four quarters of 2015. The rest of the three metros including the City of Johannesburg reported increasing trends in the unemployment rates of their populations. Nelson Mandela Bay reported the highest increase in unemployment rate followed by Ekurhuleni trailed in third place by the City of Johannesburg. The City of Johannesburg has the third highest proportion of the unemployed amongst the eight metros, but the second lowest percentage of the discouraged work seekers after the City of Cape Town. This statistic implies that the growth in young people entering the world of work is not yet being absorbed by the labor force.

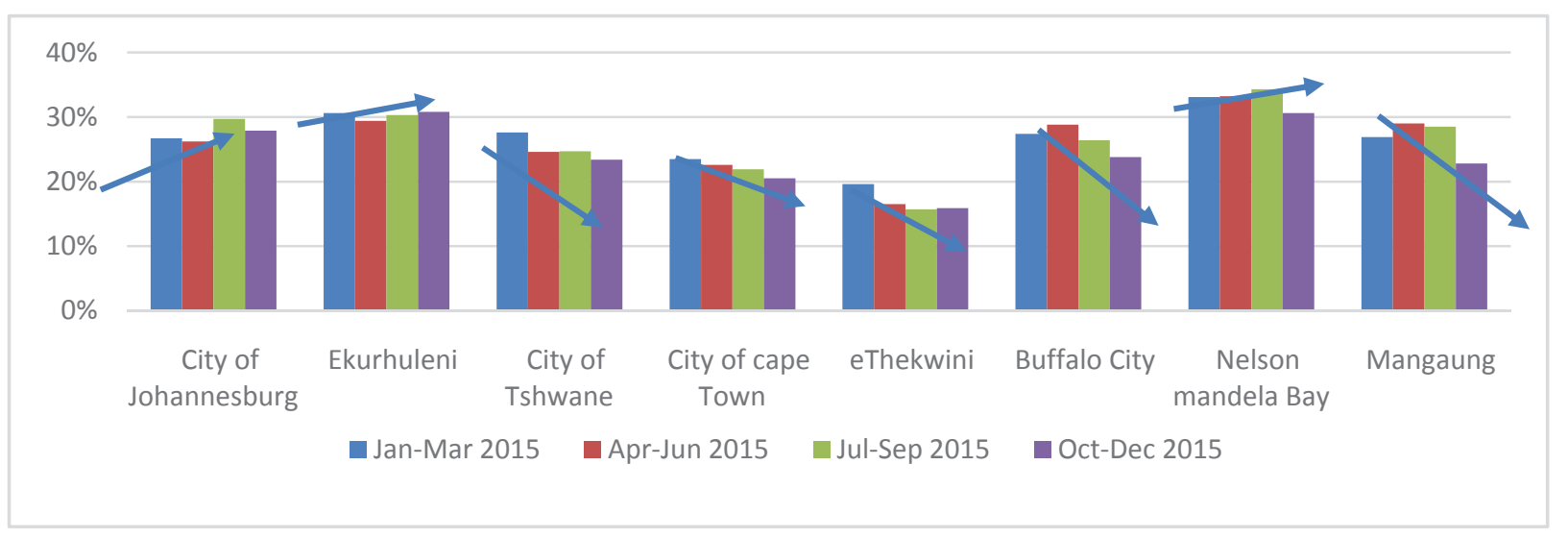

Fig. 7. The unemployment rate by metro 2015 
2.4. COJ household income and household income growth indicators 2003-2014. Figure 8 reports the results of the South African national population census in terms of the percentage growth in personal incomes in the different categories for the City of Johannesburg between 2001 and 2011 census years. The positive news is that the proportion of persons/households is increasing in the three top categories, but decreasing amongst the lowest income earning category pointing to a decreasing number of persons/households falling below the minimum wage. The negative news is that the percentage of persons within the no income category increased over the period and likewise, while there was an increase in the percentage of persons in highest income R102,401+ per month category though the increase was highly negligible indicating a slow pace in transformation towards a more equitable distribution of income over the period. As pointed out already, the NDP postulates that rising employment and productivity will lead to rising incomes and living standards and less inequality. The proportion of national income earned by the bottom $40 \%$ should rise from about $6 \%$ in 2012 and to about $10 \%$ in 2030 .

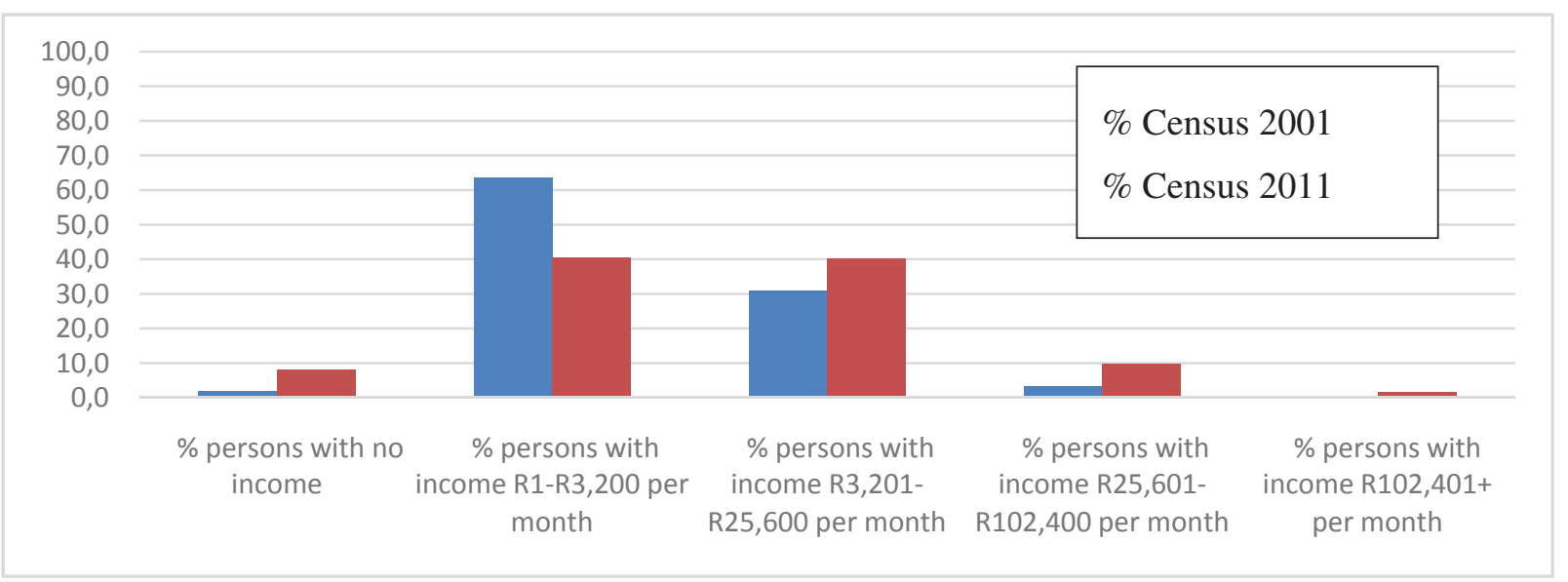

Fig. 8. Growth in the number of persons/households in the different income categories census 2001/2011

Source: Stats SA Computed by E Udjo (2016).

2.5. COJ business climate, foreign trade and investment. 2.5.1. COJ business climate. According to the World Bank (2015) study, South African entrepreneurs face different local practices depending on where they establish their business. First, there is no correlation between the size of the city (as measured by population) and the rankings, and no city does equally well in all 5 areas. In Table 1, Johannesburg and Cape Town, the largest urban centers, are the top performers on registering property and dealing with construction permits, respectively. From a public-policy point of view, such dispersion or uneven performance across the indicators measured can guide local policymakers to areas where improvements are possible without major legislative changes. Second, local improvements will not only advance the standing of one location as compared to another within South Africa, but also they can make a significant difference on the global scale, as illustrated by the distance to frontier (DTF) score. This score shows the distance between a city's performance and the "frontier," defined as the best performance globally across 189 economies.

Table 1. Doing business in Johannesburg in comparison to other South African metros

\begin{tabular}{|c|c|c|c|c|c|c|c|c|c|c|}
\hline \multirow[t]{2}{*}{$\begin{array}{l}\text { Municipality } \\
\text { Municipal Seat }\end{array}$} & \multicolumn{2}{|c|}{ Starting a business } & \multicolumn{2}{|c|}{$\begin{array}{c}\text { Dealing with } \\
\text { construction permits }\end{array}$} & \multicolumn{2}{|c|}{ Getting electricity } & \multicolumn{2}{|c|}{ Registering property } & \multicolumn{2}{|c|}{ Enforcing contracts } \\
\hline & $\begin{array}{l}\text { Ranking } \\
(1-9)\end{array}$ & $\begin{array}{l}\text { DTF } \\
\text { Score } \\
(100=\text { best } \\
\text { result) }\end{array}$ & $\begin{array}{l}\text { Ranking } \\
(1-9)\end{array}$ & $\begin{array}{l}\text { DTF } \\
\text { Score (100= } \\
\text { best result) }\end{array}$ & $\begin{array}{l}\text { Ranking } \\
(1-9)\end{array}$ & $\begin{array}{l}\text { DTF } \\
\text { Score } \\
\text { (100= best } \\
\text { result) }\end{array}$ & $\begin{array}{l}\text { Ranking } \\
(1-9)\end{array}$ & $\begin{array}{l}\text { DTF } \\
\text { Score } \\
(100= \\
\text { best } \\
\text { result) }\end{array}$ & $\begin{array}{l}\text { Ranking } \\
(1-9)\end{array}$ & $\begin{array}{l}\text { DTF } \\
\text { Score } \\
\text { (100= best } \\
\text { result) }\end{array}$ \\
\hline $\begin{array}{l}\text { Buffalo City East } \\
\text { London }\end{array}$ & 4 & 78.67 & 3 & 77.50 & 4 & 75.32 & 4 & 62.84 & 9 & 62.54 \\
\hline Cape town & 4 & 78.67 & 1 & 78.08 & 2 & 81.81 & 8 & 59.23 & 6 & 67.53 \\
\hline $\begin{array}{l}\text { Ekurhuleni } \\
\text { Germiston }\end{array}$ & 1 & 81.18 & 4 & 76.84 & 5 & 71.83 & 3 & 64.23 & 4 & 68.26 \\
\hline $\begin{array}{l}\text { eThekwini } \\
\text { Durban }\end{array}$ & 4 & 78.67 & 5 & 76.15 & 3 & 75.73 & 6 & 62.05 & 3 & 69.27 \\
\hline Johannesburg & 1 & 81.18 & 8 & 68.52 & 8 & 55.74 & 1 & 65.82 & 8 & 66.14 \\
\hline
\end{tabular}


Table 1 (cont.). Doing business in Johannesburg in comparison to other South African metros

\begin{tabular}{|c|c|c|c|c|c|c|c|c|c|c|}
\hline \multirow{2}{*}{\begin{tabular}{l}
\multicolumn{1}{c}{\begin{tabular}{c}
\multicolumn{1}{c}{ Municipality } \\
Municipal Seat
\end{tabular}} \\
Mangaung \\
Bloemfontein
\end{tabular}} & \multicolumn{2}{|c|}{ Starting a business } & \multicolumn{2}{|c|}{$\begin{array}{c}\text { Dealing with } \\
\text { construction permits }\end{array}$} & \multicolumn{2}{|c|}{ Getting electricity } & \multicolumn{2}{|c|}{ Registering property } & \multicolumn{2}{|c|}{ Enforcing contracts } \\
\hline & 4 & 78.67 & 9 & 68.22 & 1 & 83.88 & 9 & 58.41 & 1 & 71.04 \\
\hline $\begin{array}{l}\text { Msunduzi } \\
\text { Pietermarizburg }\end{array}$ & 4 & 78.67 & 6 & 74.07 & 7 & 63.00 & 7 & 59.49 & 2 & 70.81 \\
\hline $\begin{array}{l}\text { Nelson Mandela Bay } \\
\text { Port Elizabeth }\end{array}$ & 4 & 78.67 & 2 & 78.05 & 9 & 53.14 & 5 & 62.69 & 7 & 66.89 \\
\hline $\begin{array}{l}\text { Tshwane } \\
\text { Pretoria }\end{array}$ & 1 & 81.18 & 7 & 69.88 & 6 & 68.51 & 2 & 64.71 & 5 & 68.17 \\
\hline
\end{tabular}

Source: Doing Business in South Africa (2015).

Analyzing the average ranking constraint scores by business size class extracted from the Business Satisfaction Report of the Bureau of Market Research (2015). It is clear from the analysis that 'power failures' are regarded as the most serious constraint across all business size groups. This is followed by water interruptions and municipal taxes and levies.

The business vulnerability index (BVI) as a leading indicator of the level of business vulnerability in the COJ economy shows that medium and large businesses are more optimistic than small businesses regarding their financial position and sustainability. The major business constraint facing all business size groups is crime and corruption, which impacts slightly more on small and medium businesses. Also, social/political unrest is regarded as a more serious risk to medium and large businesses than to small businesses.

Turning to the international business environment, large businesses are more at risk with especially import prices cited as a major concern among these businesses. No significant differences are notable across business size regarding the Johannesburg economy and business environment. When reflecting on business competitiveness, medium and large businesses appear to be slightly more self-assured regarding conducting business in
Johannesburg and the future of business in general, when compared to small businesses. Overall, no real differences are notable in the vulnerability of businesses across business size with the overall BVI fixed at 65.02 index points.

A closer analysis of the lowest and highest risk factors inhibiting businesses from functioning optimally in the COJ clearly shows that the overwhelming majority of high risk factors causing business vulnerability and barriers to business development are exogenous to businesses. These factors fall within the field of control of government. This implies that business and government interaction within an environment of trust between the parties is essential. The main factors emerging from the business survey that contribute to a negative business sentiment generally include crime and corruption, low international economic growth and political instability with specific reference to social and political unrest (BMR, 2015)

2.5.2. COJ city finances. The Executive Mayor made a commitment to invest R100 billion in infrastructure development in the coming ten years in his 2012 State of the City address. Figure 9 highlights that the major sources of revenue for the period 2009/10 to 2015/2016 are services charges from electricity and water followed by property rates.

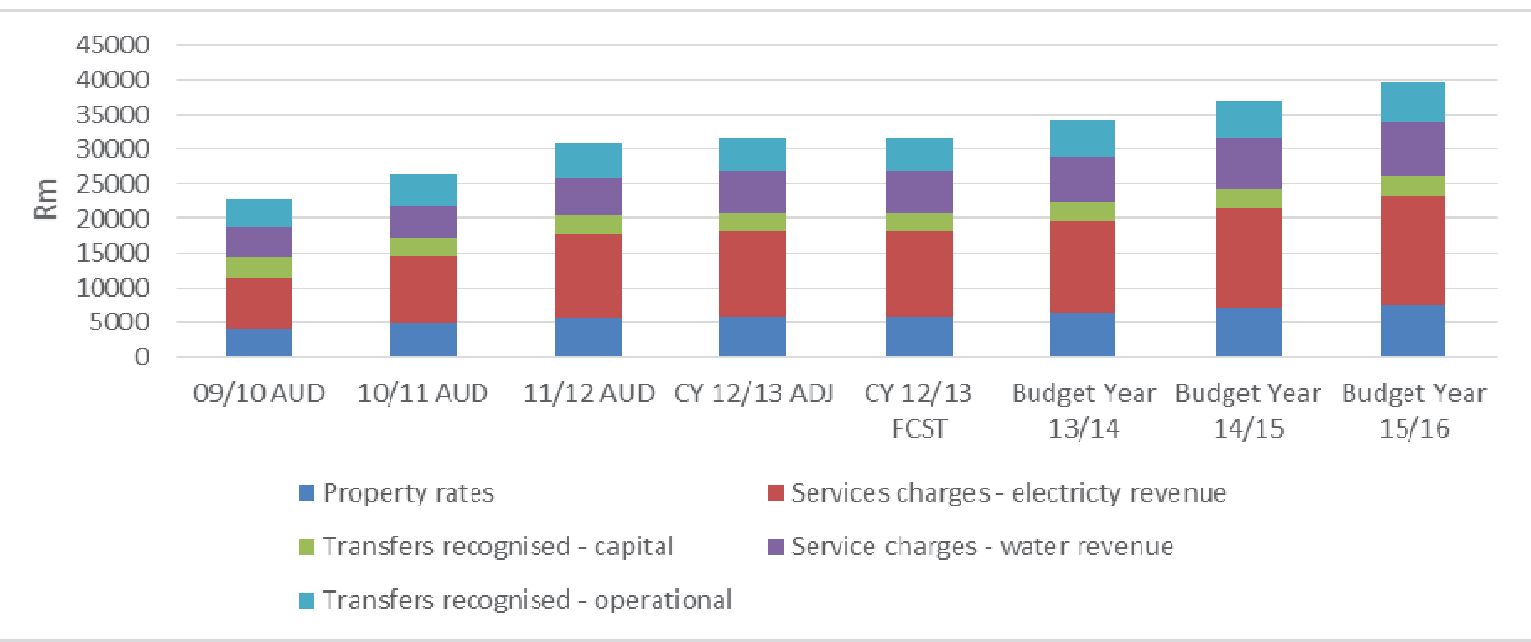

Fig. 9. Major city revenue and income sources 
The 2015/16 Medium Term Budget continues to focus on ensuring financial sustainability while delivering on the programmes outlined in the Integrated Development Plan (IDP) and the Growth and Development Strategy (GDS). It reaffirms the commitment towards the prudent management of the City's finances. In order to attain financial sustainability, the City has a set of parameters within which financial planning should be aligned and this will require generation of an annual operating surplus, prudent borrowing, creating cash reserve to increase the level of infrastructure spending and reviewing activities for operational efficiencies.

The total capital budget for the 2013/14 financial year amounted to R7.6 billion increasing from R4.5 billion in 2009/10 and reaching R11.8 billion in 2015/16, as reflected in Figure 10. Approximately R4.5 billion of the capital budget will be funded by the City and R3 billion from grants and public contributions. The proposed capital budget projects a spending plan of approximately R30.6 billion over the three-year period 2013/14 to 2015/16.

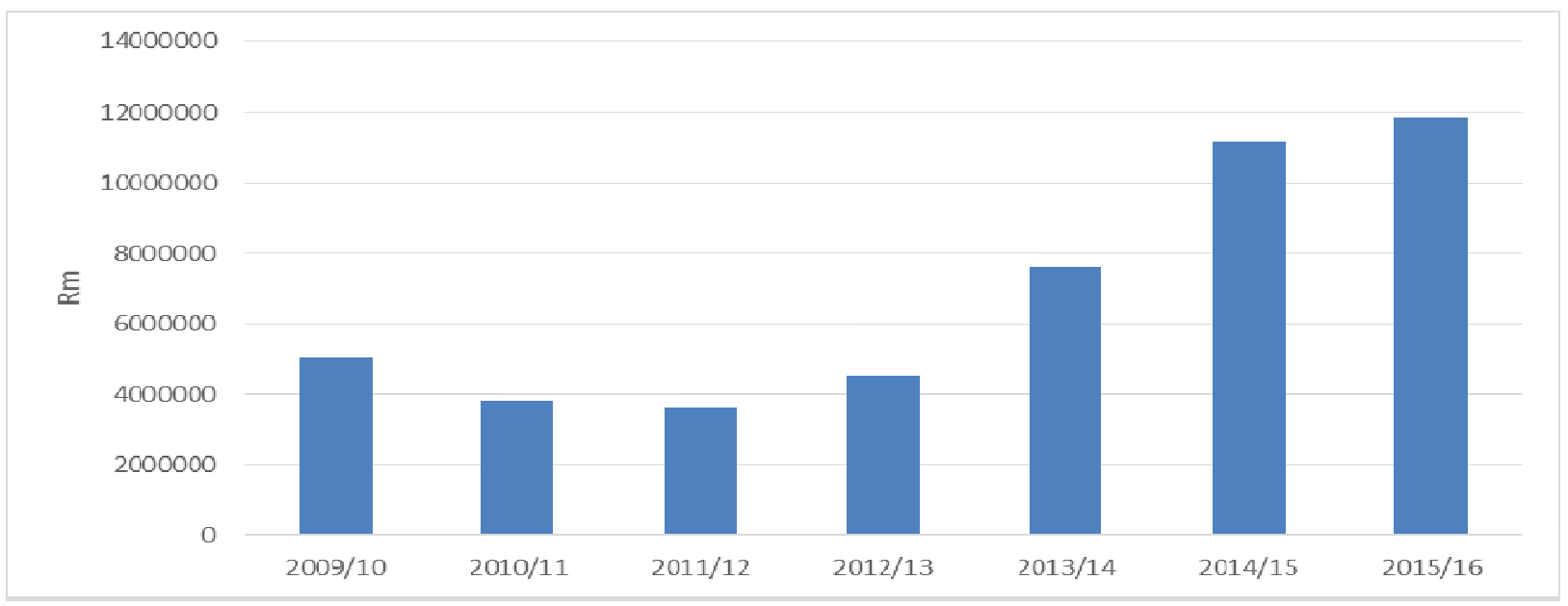

Fig. 10. COJ capital expenditure budgets

Source: COJ Medium Term Budget (2013).

2.5.3. COJ gross domestic fixed investments. According to MasterCard (2015), a range of interrelated conditions enhanced growth in most large African cities over the past decade. Of course, growth was not uniform across all cities, but conditions of life and economic opportunity have improved in most. The main driver of growth was the commodities boom and with it came improved investment, infrastructure, access to finance, a more positive business orientation, economic diversification and the expansion of the consumer sector. However, the past two years have seen a significant change in Africa's economic trajectory and this has affected its major cities.

Investment reflects the growth and relevance of each sector in the economy. Figure 11 shows that gross fixed investment in the secondary and tertiary sectors was congruent from 1995 for a period of almost 10 years. Since 2006, the secondary sector has registered the highest investment levels followed by tertiary and least the primary sector. Investment growth levels highest in the secondary sector may be a reflection of increased mechanization in the secondary sector.

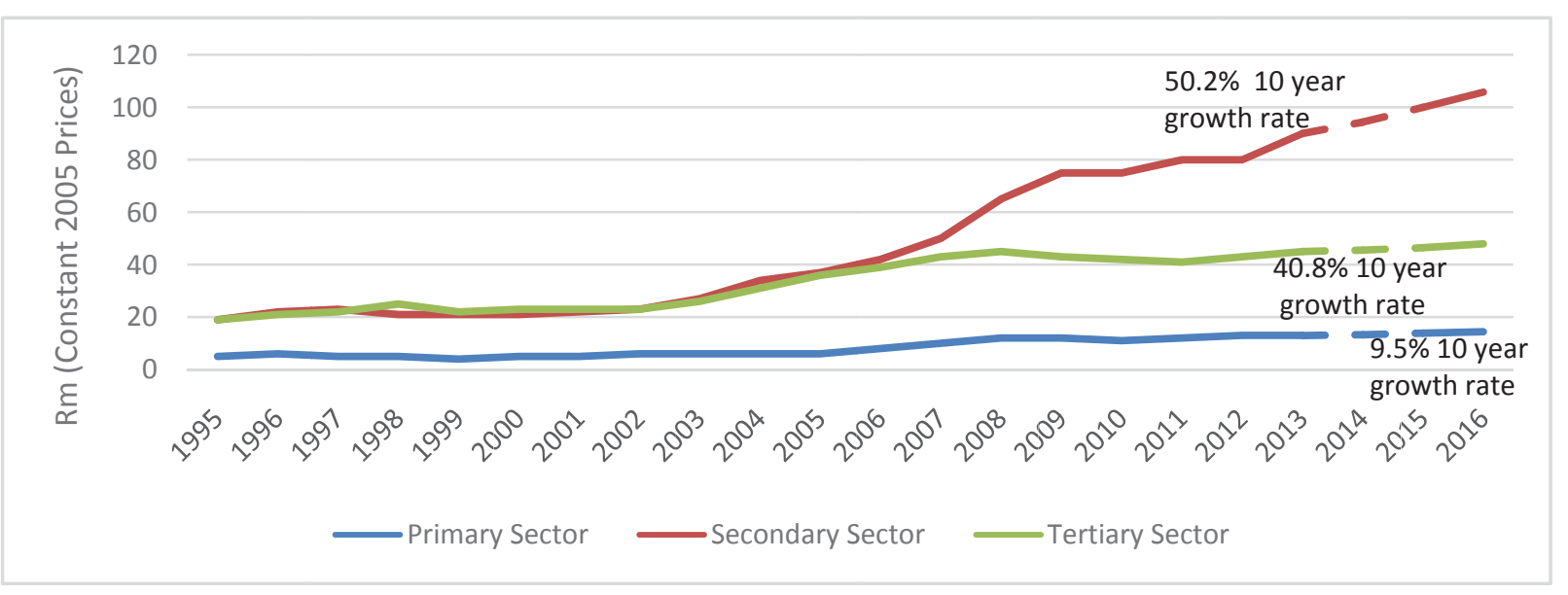

Fig. 11. COJ gross fixed investment per broad sector

Source: adopted from Quantec Database (2015). 
2.5.4. COJ foreign trade. The City of Johannesburg has been a net exporter since 2004, with the trend beginning to reverse in 2014 after 10 years to record a small trade deficit, as reflected in Figure 12. The City being a net exporter makes it highly vulnerable to both the monetary and fiscal policy of the country. For instance, high inflation increases input costs making the City export products more expensive and, hence, less competitive in international markets. While a reasonably weak rand makes the City export products cheaper, therefore, more affordable and attractive to the City trading partners.

In this regard, it is important for the City to assess and address the factors that led to the decline in export volumes in the year 2014 and ensure a net trade surplus going forward.

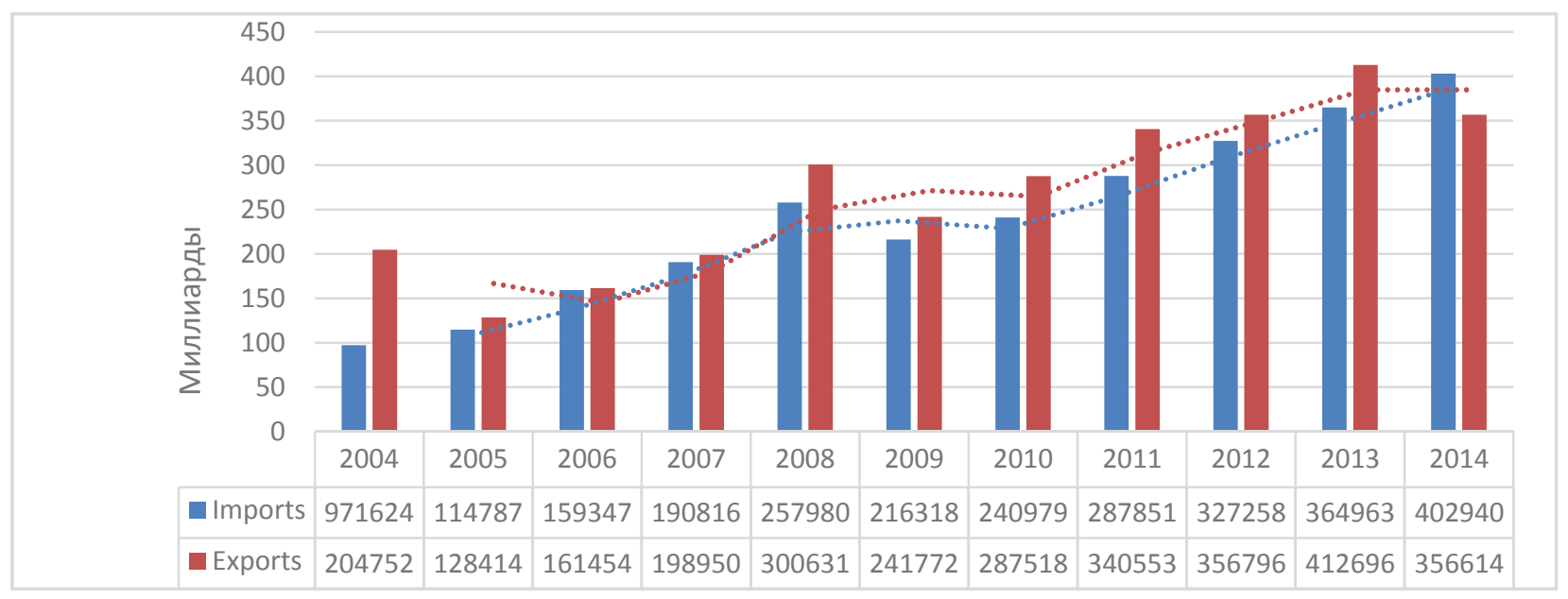

Fig. 12. The COJ import and export trends 2004-2014 current prices

Source: adopted from Quantec Database (2015).

\section{The future: how economic developments are likely to unfold}

As indicated at the outset, cities have become engines of national and global growth. By 2030, around $60 \%$ of the global population will live in urban areas. In South Africa, it is estimated that the proportion of the population living in cities will reach $80 \%$ by 2050 . The research has indicated earlier that most successful high-income countries have economically dynamic cities at the heart of their regional and national economies. Cities are also rapidly transforming the economic landscape of emerging markets where the increasing size and power of cities has brought tangible economic benefits that translate into rising incomes. In order to shape this transformation going forward, the United Nations have set 17 sustainable development goals where the countries commit to create conditions for sustainable, inclusive and sustained economic growth, shared prosperity and decent work for all, taking into account different levels of national development and capacities.

In this regard, economic growth in the City of Johannesburg from 2015 to 2018 is predicted to take two paths: firstly utilizing the autoregressive moving averages the economy is expected to grow higher than the South African economy, but continue a down ward trend for the next two years recording a growth rate of $2 \%$ in 2016 and 2017 and declining to $1 \%$ in 2018 , respectively. On other hand, based on past experience, the performance of the COJ economy may continue to align with the growth rate of the national South African economy to register close to $0.6 \%$ in 2016, $0.8 \%$ in 2017 (BMR) and $1.8 \%$ in 2018, respectively, as predicted by the Monetary Committee of the South African Reserve Bank. The implications for the slower economic growth for the City will be lower fiscal revenues raised locally from charges, rates and taxes, but also transfers from the national treasury resulting in the need to scale down on the delivery of social economic programs.

\section{City response: future priorities and recommended approaches}

Socio-economic transformation and development are a function of accelerated economic growth and pro-equity policies of public and private sector. Economic growth results in productive employment, which boosts local government revenues, that are, in turn, a key driver of inclusive growth and reduction in inequality through, amongst others, the provision of social and economic infrastructure to all communities. In this regard, the City will have to build from the base of the existing economic structure in order to broaden economic participation and inclusivity recognizing that almost three quarters of the current Gross Domestic Product and employment are generated by the service sector including finance, trade and community services. 
Two fundamental, but practical outcomes were proposed for the City's economic development strategy before and I believe are still relevant for the future: faster growth of the city economy, leading to higher employment, output and incomes, higher city revenues in order to fund ongoing city service delivery and social and economic transformation and development initiatives: economic empowerment of the poor and disadvantaged, which supports further transformation towards a fully inclusive society and economy.

Given the rate of population growth and high structural unemployment, faster economic growth alone will not be enough, the pattern of economic activity will have to support a higher aggregate rate of labor absorption than currently the case. This implies a multi-dimensional strategy, which targets the support, development and growth of the entire spectrum of business enterprise in the city ranging from the informal sector and micro enterprise to multi-national corporations. The strategy needs to stimulate economic activity and progressively empower the poor to participate in the economy.

The research also touched on the fragility of economic recovery and geopolitical turbulence, the analysis demonstrated the importance of competitiveness, understood as the drivers of higher productivity in supporting growth and economic resilience. The historic proportions of the economic crisis and the relative performance of economies have shed light on how structural weaknesses can exacerbate shocks and make an economy illequipped to respond. The crisis is a forceful reminder that competitiveness matters: regions and countries that were more competitive at the onset of the crisis are those that have weathered the crisis much better. In this context, productivity-enhancing reforms become a critical way forward.
In this regard, the city should consider a strategy that affords the council opportunity to implement and strengthen a mix of developmental objectives that are key for factor driven economies: institutions, infrastructure, microeconomic environment, health and primary education; Efficiency driven economies: higher education and training, goods market efficiency, labor market efficiency, financial market development, technological readiness and market size; innovation driven economies: business sophistication and innovation. As indicated earlier on, the aim should be to broaden economic participation and inclusivity in order to improve household incomes in the city with a view to increase consumption of both goods and services resulting in higher revenues and operating surplus for the metropolitan government to fund the delivery of social services.

\section{Conclusion}

The socio-economic structure of the City of Johannesburg has been and continues to be significantly unequal. The structure is a result of a dual economy characterized by a well-developed modern sector and a second economy each at different levels of development, technology and patterns of demand. These differentials have spelt social and economic exclusion for the majority of the residents of the City due to the lack of access to quality education, employment opportunities and a sustainable urban environment. The metropolitan council is faced with the daunting task of bridging the gap by creating conducive conditions for equitable growth through addressing both supply and demand side factors that are key to economic growth and redistribution. This will include amongst others rolling out social and economic infrastructure, skills and entrepreneurial development, building consumer and business confidence, attracting investment, providing employment opportunities and increasing municipal revenue thereby broadening economic participation and inclusivity.

\section{References}

1. Africa Progress Panel. (2014). Africa Progress Report. Grain Fish Money. Financing Africa's Green and Blue Revolutions. Geneva.

2. Africa Development Bank et al. (2015). Africa Economic Outlook - South Africa. Abidjan.

3. Bureau of Market Research. (2015). City of Johannesburg Business Satisfaction Survey. Pretoria.

4. Bureau of Market Research. (2015). Macroeconomic and Retail Trade Sales Forecast for South Africa. Pretoria.

5. Bureau of Market Research. (2016). South Africa Manufacturing PMI 1991-2016 Data. Pretoria.

6. eThekwini Metro. (2013). eThekwini Manufacturing Survey 2013. Durban.

7. eThekwini Metro. (2016). State of the eThekwini Economy. Durban in the Global Economy. Durban.

8. Floater, G. et al. (2014). Cities and the New Climate Economy.

9. International Council for Science et al. (2015). Review of Targets for the Sustainable Development Goals: The Science Perspective. Paris.

10. International Monetary Fund (IMF), January. (2016). World Economic Outlook Update. Washington DC.

11. Lewitt, S. (2002). Explaining the Johannesburg 2030 strategy. Presentation by the City of Johannesburg. Johannesburg.

12. McKinsey Global Institute. (2012). Urban World. Cities and the Rise of the Consuming Class. New York. 
13. Organization for Economic Cooperation and Development (OECD). (2012). Looking to 2060: Long-term global growth prospects. OECD Publishing. Paris.

14. PricewaterhouseCoopers (PWC). (2015). The World in 2050. Will the shift in global economic power continue? London.

15. South African Chamber of Commerce and Industry. (2016). Reticent Business Confidence. Johannesburg.

16. South African Reserve Bank. (2016). Selected Forecast Results of the Monetary Portfolio Committee Meeting March 2016. Pretoria.

17. Statistics South Africa. (2016). Gross Domestic Product $4^{\text {th }}$ quarter 2014. Tourism Satellite Account for South Africa from 2012 and Provisional for 2013 and 2014. Pretoria. Retrived from: http://www.statssa.gov.za.

18. Statistics South Africa. (2016). Gross Domestic Product $4^{\text {th }}$ quarter 2015. Pretoria. Retrived from: http://www.statssa.gov.za.

19. Statistics South Africa. (2016). Quarterly Labor Force Survey 2015. Pretoria. Retrived from: http://www.statssa.gov.za.

20. The City of Johannesburg Metropolitan Municipality. (2012). A Promising Future. The Johannesburg 2040: Growth and Development Strategy. A World Class African City. Johannesburg.

21. The City of Johannesburg. (2013) Medium Term Budget 2013 /14 - 2015/16. Johannesburg.

22. The City of Johannesburg. (2014). The Fifteen Point Economic Development Plan. Johannesburg.

23. The City of Johannesburg. (2015). Economic Development Strategy for the City of Johannesburg. Department of Economic Development. Johannesburg.

24. The Economist Intelligence Unit. (2016). Country Report South Africa. London.

25. The Mastercard. (2015). African Cities Growth Index. Cross Currents of Growth. Johannesburg.

26. The National Planning Commission. (2012). Department of the Presidency. The National Development Plan 2030. Pretoria.

27. The South African Reserve Bank. (2009). September Quarterly Bulletin. Pretoria.

28. The South African Reserve Bank. (2016). March Quarterly Bulletin. Pretoria.

29. The World Bank Group. (2015). Doing Business in South Africa 2015. Comparing Business Regulations for Domestic Firms in 9 Urban Areas and 4 Major Ports with 188 other Economies. Washington D.C.

30. The World Bank Group. (2015). The International Bank for Reconstruction and Development. Global Economic Prospects. Washington DC.

31. The World Economic Forum. (2016). Global Competitiveness Report 2015-2016. Geneva.

32. Vellala, P. et al. (2014). A Theoretical Model for Inclusive Economic Growth in Indian Context. Institute of Technology Nirma University, Ahmedabad. 